\title{
Michel Murat, L'enchanteur réticent. Essai sur Julien Gracq
}

\section{Emanuele Kanceff}

\section{Q OpenEdition \\ 1 Journals}

\section{Edizione digitale}

URL: http://journals.openedition.org/studifrancesi/35168

DOI: 10.4000/studifrancesi.35168

ISSN: 2421-5856

\section{Editore}

Rosenberg \& Sellier

\section{Edizione cartacea}

Data di pubblicazione: 1 novembre 2005

Paginazione: 450

ISSN: 0039-2944

\section{Notizia bibliografica digitale}

Emanuele Kanceff, «Michel Murat, L'enchanteur réticent. Essai sur Julien Gracq», Studi Francesi [Online], 146 (XLIX | II) | 2005, online dal 30 novembre 2015, consultato il 19 avril 2021. URL: http:// journals.openedition.org/studifrancesi/35168; DOI: https://doi.org/10.4000/studifrancesi.35168

Questo documento è stato generato automaticamente il 19 avril 2021.

\section{(c) (i) (9)}

Studi Francesi è distribuita con Licenza Creative Commons Attribuzione - Non commerciale - Non opere derivate 4.0 Internazionale. 


\title{
Michel Murat, L'enchanteur réticent. Essai sur Julien Gracq
}

\author{
Emanuele Kanceff
}

\section{NOTIZIA}

MICHEL MURAT, L'enchanteur réticent. Essai sur Julien Gracq, Paris, Librairie José Corti, 2004, pp. 358.

1 Con piacere segnaliamo questo bel saggio che unisce gusto poetico e rigore scientifico. l'autore, senza dirlo espressamente, tenta un bilancio poetico di questo squisito scrittore, cominciando dall'idea di una genesi che ha per principio il cielo e la terra, tra i quali un personaggio s'incammina. In tale modo di essere al mondo il discorso dei luoghi investe l'opera in tutta la sua estensione e nel suo più intimo essere, come rivelano i titoli che lo scrittore ha scelto per i suoi romanzi. Dunque, la personalità dello scrittore si forma tra luoghi e libri e il viaggio tra i luoghi conduce alla scrittura. Sono i luoghi a costituire il punto di partenza della finzione e spesso anche il tema principale del libro: Gracq vive dunque, ad esempio, la Roma di Stendhal e di Chateaubriand prima di conoscerla in proprio e di scriverne. Murat sostiene che la tematica spaziale occupa il primo posto nell'opera di Gracq esostituisce la psicologia e la morale. Non è questo, tuttavia, un atteggiamento romantico, come potrebbe apparire a prima vista: l'individuo non fa del mondo il teatro dell'anima, non vi colloca né il suo desiderio né il suo rimpianto. La sua soggettività si costruisce in rapporto al luogo e all'ora e non esiste al di fuori di tale rapporto, sicché la condizione umana è per lui una ricettività vegetativa.

2 Tale condizione fonda la sua morale di scrittore, ripudio interiore e non violento dell'ordine sociale,che ha come solo fine la letteratura, fuori da ogni possibile discussione con le avanguardie poetiche che gli sono contemporanee.

3 L'autore studia dunque «il genio dei luoghi» in Gracq, il suo aspetto romanzesco, la sua dimensione critica, per giungere a tratteggiare in un capitolo conclusivo «le déserteur 
de l'avant-garde». Molto opportunamente, in una ulteriore parte del denso studio, passa in rassegna le singole opere di Gracq, concludendo poi la sua serrata e poetica lettura con una ricca cronologia e una sostanziosa bibliografia. 